\title{
Optimum Alkaline Electrolyzer-Proton Exchange Membrane Fuel Cell Coupling in a Residential Solar Stand-Alone Power System
}

\author{
Hany A. Khater, Amr A. Abdelraouf, and Mohamed H. Beshr \\ Department of Mechanical Power Engineering, Faculty of Engineering, Cairo University, P.O. Box 12211, Giza, Egypt \\ Correspondence should be addressed to Mohamed H. Beshr, mbeshr@ymail.com
}

Received 22 July 2011; Accepted 4 September 2011

Academic Editors: K. Kaygusuz and A. Stoppato

Copyright (๑) 2011 Hany A. Khater et al. This is an open access article distributed under the Creative Commons Attribution License, which permits unrestricted use, distribution, and reproduction in any medium, provided the original work is properly cited.

\begin{abstract}
Modeling of an alkaline electrolyzer and a proton exchange membrane fuel cell (PEMFC) is presented. Also, a parametric study is performed for both components in order to determine the effect of variable operating conditions on their performance. The aim of this study is to determine the optimum operating conditions when the electrolyzer and the PEMFC are coupled together as part of a residential solar powered stand-alone power system comprising photovoltaic (PV) arrays, an alkaline electrolyzer, storage tanks, a secondary battery, and a PEMFC. The optimum conditions are determined based on an economic study which is performed to determine the cost of electricity (COE) produced from this system so as to determine the lowest possible COE. All of the calculations are performed using a computer code developed by using MATLAB. The code is designed so that any user can easily change the data concerning the location of the system or the working parameters of any of the system's components to estimate the performance of a modified system. Cairo city in Egypt was used as the place at which the output of the system will be determined. It was found that the optimum operating temperature of the electrolyzer is $25^{\circ} \mathrm{C}$. Also, the optimum coupling pressure of the electrolyzer and the PEMFC is 4 bars. The operating temperature of the PEMFC had a slight effect on its performance while an optimum current density of $400 \mathrm{~mA} / \mathrm{cm}^{2}$ was detected. By operating the fuel cell at optimum conditions, its efficiency was found to be $64.66 \%$ with a need of $0.5168 \mathrm{Nm}^{3}\left(\mathrm{Nm}^{3}\right.$ is a $\mathrm{m}^{3}$ measured at temperature of $0^{\circ} \mathrm{C}$ and pressure of 1 bar) of hydrogen to produce $1 \mathrm{kWh}$ of electricity while its cogeneration efficiency was found to be $84.34 \%$. The COE of the system was found to be 49 cents/kWh, at an overall efficiency of $9.87 \%$, for an operational life of 20 years.
\end{abstract}

\section{Introduction}

The use of nonrenewable fuel diminishes as time goes on. This is simply because such type of fuel will vanish at some point of time. Also, the increased use of biomass has had a negative effect on global warming and dramatically increased food prices by diverting forests and crops into biofuel production. Thus, the need of renewable sources of energy becomes a fact of life. Solar energy is the greatest available source of renewable energy.

Using solar energy appears to be a promising option. However, some serious concerns about its implementation include the cost of electricity obtained from solar source as well as the intermittent nature in solar power production. In order to overcome the latter concern, a system that can be used to utilize solar energy is proposed. Also, an investigation of the cost related to such system is included.

The proposed system, shown in Figure 1, comprises photovoltaic arrays, a battery, an alkaline electrolyzer, hydrogen storage system, and a proton exchange membrane fuel cell. This system is studied mainly with the aim of being applied as a stand-alone power system for residential houses to overcome the need of being connected to an electricity grid. First of all, the solar energy is directly converted to electric energy through the photovoltaic arrays. Then, this electric power can be directed to one of two routes, whether to the electrolyzer or the battery. During the presence of sunlight, the electric power is used to charge the battery which in turn satisfies the demand load at this period of time. That is, the electric power is not stored in the battery; the power is passed 


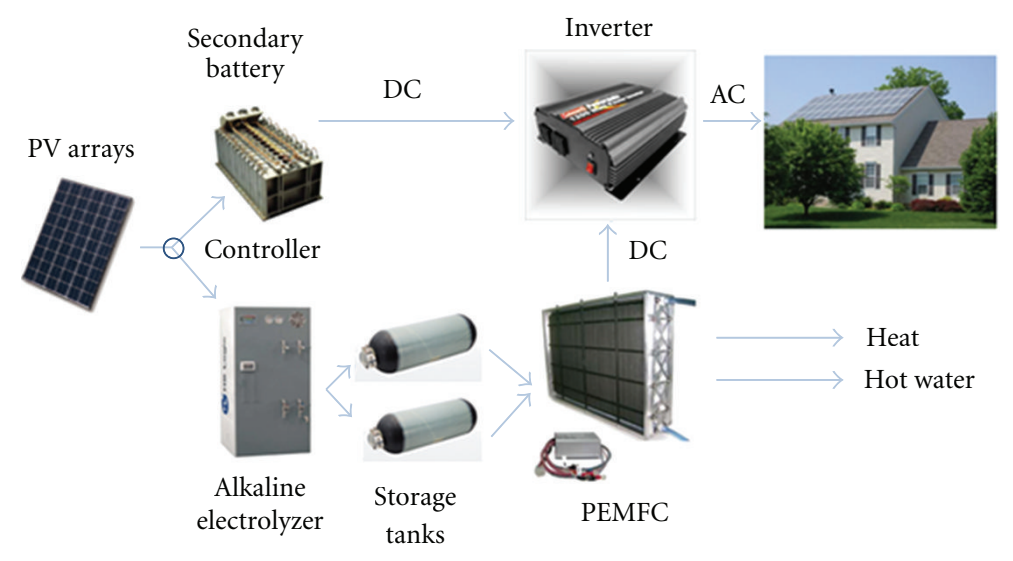

Figure 1: Schematic of system.

through the battery to the load continuously which means that the battery just regulates the voltage and current of the power supply to match the needs of the load. However, an extra power, more than the demand load, will exist at most periods of sunlight duration. If the extra power is less than $10 \%$ than that of the electrolyzer, it cannot practically be utilized by the electrolyzer and so it is used to charge the battery. In case the battery is fully charged, this electric power is dumped and wasted as we cannot make use of it in any of the two devices. On the other hand, if the extra electric power provided from the PV arrays is more than $10 \%$ of the power required by the electrolyzer, it is used to operate the electrolyzer and generate hydrogen. The hydrogen is then stored in storage tanks to be used later to generate electricity by the PEM fuel cell. The fuel cell is considered as a secondary source of electricity. That is, the demand load at periods where there is no sunlight is fulfilled at first from the power of the battery until all of the battery's power is utilized. Further demand load is then satisfied by operating the fuel cell. Also, any extra amount of hydrogen stored can be compressed and used as fuel for a household car operated by a fuel cell.

The modeling of the system as a whole was presented by Khater et al. [1]. However, it is clear from Figure 1 and the system description that there is no compressor used to compress the hydrogen before storing in the tanks and utilizing it by the PEMFC. Thus, the modeling of the electrolyzer and the PEMFC is presented in details in this paper as well as a parametric study for both devices. Also, an optimization of the electrolyzer-PEMFC coupling in order to yield the maximum output from the system and hence the lowest COE is critical and studied in details in this paper.

\section{Mathematical Model}

\subsection{Electrolyzer}

2.1.1. Thermodynamic Model. A brief description of the thermodynamics of the low-temperature hydrogen-oxygen electrochemical reactions used in the electrolyzer model is explained in this part. A maximum electrolyzer temperature of $100^{\circ} \mathrm{C}$ was assumed.
The following assumptions can be made about the water splitting reaction: (a) hydrogen and oxygen are ideal gases, (b) water is an incompressible fluid, and (c) the gas and liquid phases are separate. Based on these assumptions the change in enthalpy $\delta h$, entropy $\delta s$, and Gibbs energy $\delta g$ of the water splitting reaction can be calculated with reference to pure hydrogen $\left(\mathrm{H}_{2}\right)$, oxygen $\left(\mathrm{O}_{2}\right)$, and water $\left(\mathrm{H}_{2} \mathrm{O}\right)$ at standard temperature and pressure $\left(25^{\circ} \mathrm{C}\right.$ and 1 bar) [2]. The total change in enthalpy for splitting water is the enthalpy difference between the products $\left(\mathrm{H}_{2}\right.$ and $\left.\mathrm{O}_{2}\right)$ and the reactants $\left(\mathrm{H}_{2} \mathrm{O}\right)$. The same applies for the total change in entropy. The change in Gibbs energy is expressed by

$$
\delta h=\delta g+T \delta s .
$$

The standard Gibbs energy for water splitting is $\delta g^{\circ}=$ $237.178 \mathrm{~kJ} \mathrm{~mol}^{-1}$. For an electrochemical process operating at constant pressure and temperature, the maximum possible useful work (i.e., the reversible work) is equal to the change in Gibbs energy $\delta g$. The reversible potential $\left(V_{\text {rev }}\right)$ represents the minimum amount of energy that can be supplied in the form of electricity to perform the electrolysis of water. It is expressed by

$$
V_{\text {rev }}=\frac{\delta \mathrm{g}}{z F},
$$

where $\mathrm{z}$ is the number of electrons transferred per hydrogen molecule which is equal to 2 and $F$ is the Faraday constant and is equal $96485 \mathrm{C} \mathrm{mol}^{-1}$.

The thermodynamic voltage for water splitting $\left(V_{\text {rev }}\right)$ reduces with an increase in operating temperature as given by the following relation [3] (where $T$ is in Kelvins):

$$
\begin{aligned}
V_{\mathrm{rev}, T}= & 1.5184-1.5421 * 10^{-3} * T \\
& +9.523 * 10^{-5} * T * \ln T+9.84 * 10^{-8} * T^{2} .
\end{aligned}
$$

The rest of the energy required to achieve $\delta h$, or the thermoneutral potential $\left(V_{\mathrm{tn}}\right)$, can be supplied as heat $(T \delta S)$ at a temperature that is high enough. The standard enthalpy 
for splitting water is $\delta h^{\circ}=286 \mathrm{~kJ} \mathrm{~mol}^{-1}$. The thermoneutral potential is expressed by

$$
V_{\mathrm{tn}}=\frac{\delta h}{z F}
$$

At standard conditions,

$$
\begin{gathered}
V_{\text {rev }}=\frac{237178}{2 * 96485}=1.229 \mathrm{~V}, \\
V_{\mathrm{tn}}=\frac{286000}{2 * 96485}=1.482 \mathrm{~V} .
\end{gathered}
$$

These will change with temperature and pressure. In the applicable temperature range, $V_{\text {rev }}$ decreases slightly with increasing temperature $\left(V_{\text {rev at }} 80^{\circ} \mathrm{C}, 1 \mathrm{bar}=1.184 \mathrm{~V}\right)$, while $V_{\text {tn }}$ remains almost constant $\left(V_{\text {tn at } 80^{\circ} \mathrm{C}, 1 \text { bar }}=1.473 \mathrm{~V}\right)$. Increasing pressure increases $V_{\text {rev }}$ slightly $\left(V_{\text {rev at }} 25^{\circ} \mathrm{C}, 30 \mathrm{bar}=\right.$ $1.295 \mathrm{~V}$ ), while $V_{\text {tn }}$ remains constant. It is worth noting that the values of $V_{\text {rev }}$ used in this thesis are obtained from (3). Thus, it is important to compare the obtained empirical values with the previously mentioned exact values.

Using (3),

(i) at standard conditions: $V_{\text {rev }}=1.2293 \mathrm{~V}$,

(ii) $V_{\text {rev at } 80^{\circ} \mathrm{C}, 1 \mathrm{bar}}=1.1835 \mathrm{~V}$.

\subsubsection{Electrochemical Model}

I-V Curve. The curve which is used to model the electrolyzer is the $I-V$ curve. That is, the curve of the cell voltage against the current. The basic form of the $I-V$ curve is given by [2]:

$$
V=V_{\text {rev }}+\frac{r}{A} I+s \log \left(\frac{t}{A} I+1\right) .
$$

In order to properly model the temperature dependence of overvoltages, the following form was proposed by Ulleberg [2] and presented graphically in Figure 2

$$
V=V_{\mathrm{rev}}+\frac{r_{1}+r_{2} T}{A} I+s_{1} \log \left(\frac{t_{1}+t_{2} / T+t_{3} / T^{2}}{A} I+1\right),
$$

where: $r_{1}, r_{2}$ are ohmic resistance coefficients and $s_{1}, t_{1}, t_{2}, t_{3}$ are overvoltage coefficients.

Table 1 represents the values of the above parameters used in (6b) [2].

In order to find the six parameters needed in the proposed empirical $I-V$ relationship (6b), a systematic sevenstep procedure for obtaining the best possible curve fit is presented as follows [2].

(1) Collect experimental or operational data for current $I$, voltage $V$, and temperature $T$.

(2) Organize the measured values for $I$ and $V$ in sets with respect to constant values for $T$.

(3) Perform individual curve fits of the three coefficients $r, s_{1}$, and $t$ in (6a).
TABLE 1: $I-V$ curve parameters of (6b).

\begin{tabular}{lc}
\hline$r_{1}$ & $8.05 e-5 \Omega \mathrm{m}^{2}$ \\
$r_{2}$ & $-2.5 e-7 \Omega \mathrm{m}^{2}{ }^{\circ} \mathrm{C}^{-1}$ \\
$s_{1}$ & $0.185 \mathrm{~V}$ \\
$t_{1}$ & $-1.002 \mathrm{~A}^{-1} \mathrm{~m}^{2}$ \\
$t_{2}$ & $8.424 \mathrm{~A}^{-1} \mathrm{~m}^{2}{ }^{\circ} \mathrm{C}$ \\
$t_{3}$ & $247.3 \mathrm{~A}^{-1} \mathrm{~m}^{2}{ }^{\circ} \mathrm{C}^{2}$ \\
\hline
\end{tabular}

(4) Repeat step (3) for few other temperatures (e.g., $T=$ $\left.20^{\circ} \mathrm{C}-80^{\circ} \mathrm{C}\right)$.

(5) Perform intermediate curve fits on the temperaturedependent coefficients $r$ and $t$.

(6) Verify that the temperature-dependent coefficients in (6b) behave according to the expressions:

$$
r(T)=r_{1}+r_{2} T, \quad s_{1}=t_{1}+\frac{t_{2}}{T}+\frac{t_{3}}{T^{2}} .
$$

(7) Perform an overall curve fit on the entire data set, using the values for the parameters $r_{i}, s_{1}$, and $t_{i}$ found from steps (1) to (6) as initial values for the regression.

As mentioned before, the operation voltage of the used electrolyzer is in the range $30-40 \mathrm{~V}$, depending on the current obtained from the PV panels. That is, for any increase in the power output of the PV array, part of it causes an increase in the operating current density of the electrolyzer while the other part helps to overcome the increase in the needed working electric potential of an electrolysis cell $(V)$.

Actually, the working electric potential of an electrolysis cell $(V)$ is always higher than the reversible potential due to process irreversibilities, resulting in a loss of efficiency. The potential can be written as the sum of several contributions as follows [4]:

$$
V=V_{\text {rev }}+V_{\text {anode }}+V_{\text {cathode }}+V_{\text {Ohm }} .
$$

$V_{\text {anode }}$ and $V_{\text {cathode }}$ are the anodic and cathodic overpotentials, respectively. Their origin lies in the activation energy of the electrochemical processes taking place on the electrodes. These overpotentials increase logarithmically with the electrical current density and depend strongly on the electrocatalytic activity of the electrode materials. The origin of $V_{\mathrm{Ohm}}$ is very different because it is the ohmic loss of potential mainly associated to the resistance to the flow of ions across the several components of the electrolysis cell, especially the membranes and the electrolyte. The value of this overpotential increases linearly with the current density and decreases with the electric conductivity of the electrolyte and membranes and on decreasing the distance between the electrodes [4]. As the specific conductivities of the alkaline solutions used as electrolytes increase almost linearly with temperature [5], there is a positive effect of the temperature on the process since the ohmic overpotential is reduced. Nevertheless, the cell potential may reach values between 1.7 and $1.9 \mathrm{~V}$ in modern alkaline water electrolyzers when 


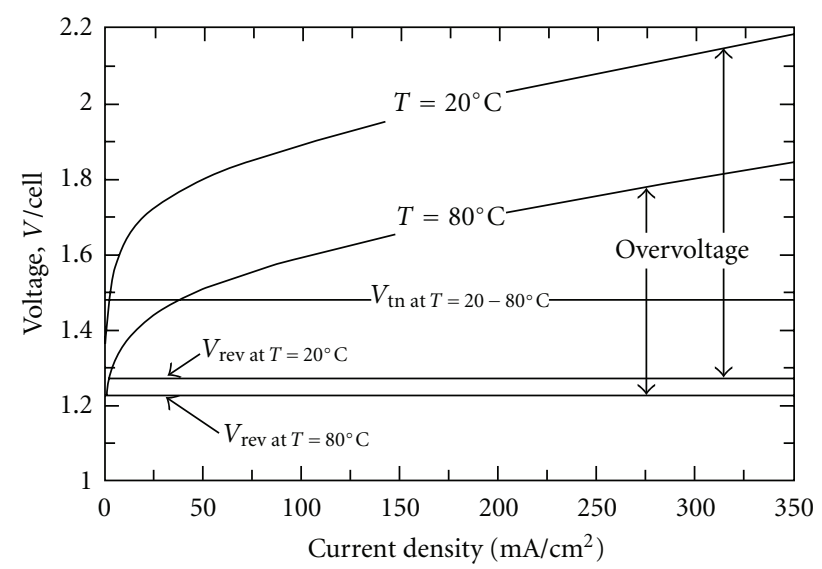

FIgURE 2: Typical $I-V$ curves for an electrolyzer cell at high and low temperatures [2].

operated at relatively high current densities $\left(1 \mathrm{~A} / \mathrm{cm}^{2}\right)$ [6]. This is an electric potential considerably higher than the thermoneutral voltage, and, as a result, water electrolysis is accompanied by the release of heat in spite of being an endothermic process. This waste heat allows maintaining the electrolysis temperature, and it is produced at a rate directly proportional to the difference between the actual cell potential and the thermoneutral voltage.

The efficiency of water electrolysis is defined as the ratio of hydrogen energy content (the energy that can be recovered by reoxidation of the hydrogen and oxygen to water) to the electrical energy supplied to the electrolyzer [2]. In terms of voltage, the efficiency can be expressed as

$$
\eta_{\mathrm{e}}=\frac{V_{\mathrm{tn}}}{V}
$$

For a given temperature, an increase in hydrogen production (i.e., an increase in current density) increases the cell voltage, which consequently decreases the energy efficiency. For a given current density, the energy efficiency increases with increasing cell temperature. It should be noted here that (9) is only valid for systems where no auxiliary heat is added to the system. If auxiliary heat is added, the voltage may, at very low current densities, drop into the region between the reversible and thermoneutral voltage, and the efficiency, as defined by (9), would be greater than $100 \%$ [2].

The heat absorbed by the cooling water of the electrolyzer makes it possible to use this hot water for domestic purposes by the house residents. This heat is obtained from (10a) as follows [2]:

$$
\begin{gathered}
\dot{Q}_{\text {cool }}=\dot{Q}_{\text {gen }}-\dot{Q}_{\text {loss }}, \\
\dot{Q}_{\text {gen }}=n_{c} V I\left(1-\eta_{e}\right), \\
\dot{Q}_{\text {loss }}=\frac{1}{R_{t}}\left(T-T_{a}\right),
\end{gathered}
$$

where $R_{t}$ is the overall thermal resistance of the electrolyzer which was found experimentally to be $0.167^{\circ} \mathrm{C} \mathrm{W}^{-1}$.

Hydrogen Production Rate. The Faraday efficiency is defined as the ratio between the actual and theoretical maximum amount of hydrogen produced in the electrolyzer. An increase in temperature leads to a lower resistance, more parasitic currents losses, and lower Faraday efficiencies. An empirical expression that accurately depicts these phenomena for a given temperature is the Faraday's efficiency $\left(\eta_{F}\right)$ given as

$$
\eta_{F}=\frac{(I / A)^{2}}{f_{1}+(I / A)^{2}} f_{2}
$$

The parameters in the above equation are given in Table 2 shown below.

Hence, the total hydrogen production rate in an electrolyzer, which consists of several cells connected in series, can be expressed as

$$
\begin{aligned}
& \dot{n}_{\mathrm{H}_{2}}=\eta_{F} \frac{n_{c} I}{z F}, \\
& \dot{n}_{\mathrm{H}_{2}}=\dot{n}_{\mathrm{H}_{2} \mathrm{O}}=2 \dot{n}_{\mathrm{O}_{2}} .
\end{aligned}
$$

The volume flow rate of hydrogen $(Q)$ in $\mathrm{Nm}^{3} / \mathrm{h}$ is calculated as

$$
Q=\dot{n}_{\mathrm{H}_{2}} * 3600 * 0.022414 .
$$

2.1.3. Electrolyzer Parameters and Improvements. There is a need for an improvement in global energy efficiency of water electrolyzers and particularly in the reduction of the electric energy consumption of the electrolysis module, without decreasing the productivity.

Concerning the design of the electrolysis stack, new electrolysis cells' configurations have been developed to reduce the internal electric resistance. The so-called zero-gap is the configuration adopted by most of the manufacturers. A number of investigations have been carried out aiming at achieving further performance improvements [2].

Nadal et al. [7] have analyzed the influence of the gas bubbles generated by electrodes separated by different distances in order to investigate the possible existence of an optimum separation that maximizes the electrolysis efficiency. Ramadan et al. [8] have also studied the effect 
TABle 2: Faraday efficiency parameters (11).

\begin{tabular}{lc}
\hline$T$ & $80^{\circ} \mathrm{C}$ \\
$f_{1}$ & $250 \mathrm{~mA}^{2} \mathrm{~cm}^{-4}$ \\
$f_{2}$ & 0.96 \\
\hline
\end{tabular}

of the separation distance of electrodes on the hydrogen production rate.

Schiller et al. [9] have obtained a reduction in the anodic and cathodic overvoltages of about $15 \%$ when using highperformance electrodes produced by means of the vacuum plasma spraying (VPS) technology. They were tested in intermittent operating conditions supplied by a photovoltaic system.

It has been reported that additional reductions of energy needs can be achieved by adding ionic activators into the electrolyte and changing cell geometries [10]. Ramadan et al. [8] have reported that increasing the cell size, which means an increase in the solution size, increases the flow rate of $\mathrm{H}_{2}$ production. This is simply due to the increase in electron emission. Also, increasing the cell size speeds the overall reaction with increasing the contact area. However, after a certain size, the resistance of the solution increases which causes decay in the hydrogen production rate and the speed of the reaction.

In other works, the process efficiency has been increased with improved membranes properties and materials [11]. There have also been conducted several studies on the influence of the electrolysis pressure on the energy efficiency, although it seems that there is still no general agreement about this question. In this regard, Onda et al. [12] have pointed out that high-pressure water electrolysis consumes up to $5 \%$ less energy than atmospheric water electrolysis. Rzayeva et al. [13] have agreed with this effect. On the contrary, Roy et al. [14] have found that atmospheric electrolyzers have an efficiency that can be up to $16 \%$ higher than that of the high-pressure ones.

2.2. Fuel Cell. An analytical simulation model of the PEMFC is presented in this part. Assuming in this model that the fuel is pure hydrogen at inlet to the anode and the oxidant is pure oxygen at inlet to the cathode. The fuel cell model implemented in this work, known as the Generalized Steady State Electrochemical Model (GSSEM), is zero dimensional, semiempirical, and static in nature, thus the parameters of the equations are determined experimentally to provide the time-independent polarization curves, power curves, and efficiencies at various operating conditions, and the model is applicable to an entire fuel cell. The voltage of the fuel cell is modeled as [15]:

$$
V_{\text {cell }}=E_{\text {Nernst }}-V_{\text {act }}-V_{\text {ohm }}-V_{\text {conc }}
$$

where $E_{\text {Nernst }}$ is the Nernst voltage, which is the expression for the electromotive force (EMF) for given product and reactant activities; $V_{\text {act }}$ is the activation overvoltage, which is the amount of voltage used to drive the reaction; $V_{\mathrm{ohm}}$ is the ohmic overvoltage, which is the amount of voltage lost due to the resistance to electron flow in the electrodes and the resistance to ion flow in the electrolyte; $V_{\text {conc }}$ is the concentration overvoltage, which is the voltage lost when the concentration of reactant at the electrode is diminished.

Mann et al. [16] have expressed the Nernst voltage by the following equation as a function of operating temperature and pressure of the cell:

$$
\begin{aligned}
E_{\text {Nernst }}= & 1.229-0.85 * 10^{-3}\left(T_{\text {cell }}-298.15\right)+4.3085 \\
& * 10^{-5} * T_{\text {cell }}\left(\ln \left(p_{\mathrm{H}_{2}}^{\text {interface }}\right)+0.5 \ln \left(p_{\mathrm{O}_{2}}^{\text {interface }}\right)\right),
\end{aligned}
$$

where $T_{\text {cell }}$ is the stack temperature (in $\mathrm{K}$ ) and $p_{\mathrm{H}_{2}}^{\text {interface }}$ and $p_{\mathrm{O}_{2}}^{\text {interface }}$ are the hydrogen and oxygen partial gas pressures (in $\mathrm{atm}$ ) at the surface of the catalyst at the anode and cathode, respectively. It should be noted that there is no term for the partial pressure of the water product in (15). The assumption has been made that the water product is in pure liquid form and that a thin film of liquid water covers the catalyst and allows the reactants to diffuse through the water.

It is further noted that the expression in (15) for the Nernst voltage incorporates the voltage loss due to fuel crossover (where $\mathrm{H}_{2}$ passes through the electrolyte without reacting) and internal current (where electrons pass through the membrane rather than through the electrodes). The partial pressures at the catalyst surface are assumed to be the same across the entire cell [17]:

$$
\begin{aligned}
& p_{\mathrm{H}_{2}}^{\text {interface }}=\frac{2}{3} * p_{\text {cell }}, \\
& p_{\mathrm{O}_{2}}^{\text {interface }}=\frac{1}{3} * p_{\text {cell }},
\end{aligned}
$$

where $p_{\text {cell }}$ is the operating pressure of the fuel cell.

The reaction would produce a maximum amount of useful work if all the free energy is directed to transfer electrons from one electrode to the other. The value of maximum obtainable work from a fuel cell is given by [18]:

$$
W_{\text {max,elec }}=-\Delta G=z * F * E_{\text {Nernst }} .
$$

Deviation from the ideal values of cell voltage is due to the losses one would experience when current is to be induced between cell electrodes. There are three types of losses as mentioned earlier and as detailed below.

(1) Activation losses that are caused by the slowness of the reactions taking place on the surface of the electrodes (the activation of the anode and the cathode). A proportion of the voltage generated is lost in driving the chemical reaction that transfers the electrons to or from the electrodes. This voltage drop is highly nonlinear. For most values of overvoltage, one may use the following equation [19]:

$$
V_{\mathrm{act}}=A_{T} * \ln \left[\frac{\left(i+i_{n}\right)}{i_{0}}\right],
$$

where $A_{\mathrm{T}}$ is the slope of the Tafel line $\left\{A_{\mathrm{T}}=R_{\mathrm{gc}} *\right.$ $\left.T_{\text {cell }} /(2 * 0.5 * F)\right\}$ (Volt); $i$ is the current density 
$\left(\mathrm{mA} / \mathrm{cm}^{2}\right) ; i_{n}$ is the internal and fuel crossover equivalent current density $\left(\mathrm{mA} / \mathrm{cm}^{2}\right) ; i_{0}$ is either the exchange current density at the cathode if the cathodic overvoltage is much greater than the anodic, or it is a function of both exchange current densities $\left(\mathrm{mA} / \mathrm{cm}^{2}\right)$.

(2) Ohmic losses are due to the electrical resistance (electrons) of the electrodes and the resistance to the flow of ions (protons) in the electrolyte. To be consistent with the other equations for voltage loss, the equation should be expressed in terms of current density. The equation for the voltage drop then becomes [19]

$$
V_{\mathrm{ohm}}=\left(i+i_{n}\right) * r,
$$

where $r$ is the area specific resistance (ASR) $\left(\mathrm{k} \Omega \cdot \mathrm{cm}^{2}\right)$.

(3) Concentration losses are the result of the pressure drop of the reactant gases. The overvoltage depends on the amount of current drawn from the cell, as well as the physical characteristics of the gas supply systems. In general, concentration or mass transport losses are given by [19]

$$
V_{\mathrm{conc}}=m * e^{(n * i)}
$$

where $m$ and $n$ are the constants in the mass transfer overvoltage.

The constant values used in this work are given in Table 3 [20].

The main outputs of the fuel cell operation are power, water, and heat production. The power output of a fuel cell is the most important measure of its performance. Much of the current research in the area of fuel cells is focused on attempts to increase the power output while decreasing the manufacturing costs. The gross output of the fuel cell stack (in $\mathrm{W}$ ) is given by:

$$
W_{\text {cell }}=I * V_{\text {cell }} \text {, }
$$

where $I$ is the total direct current (DC) generated by the fuel cell.

A power conditioning unit is required to convert the DC current into alternating current (AC) current. The net power output in $\mathrm{AC}$ of the fuel cell stack is a more important consideration when assessing its performance and is given by

$$
P_{\text {net,cell }}=W_{\text {cell }} * \eta_{\mathrm{pc}},
$$

where $\eta_{\mathrm{pc}}$ is the power conditioning efficiency (assumed to be 0.99$)$.

Similarly, in this model of the stand alone PEMFC, the cell electrical efficiency was calculated as the cell gross power output divided by the heating value of the hydrogen inlet to the cell $\left(\eta_{\text {cell }}\right)$ :

$$
\eta_{\mathrm{pc}}=W_{\mathrm{cell}} /\left(\dot{m}_{\mathrm{H}_{2}, \text { in }} * \mathrm{LHV}\right)
$$

TABle 3: Constants used to calculate potential losses for lowtemperature PEMFC.

\begin{tabular}{lcc}
\hline Constant & Units & Value \\
\hline$i_{n}$ & $\left(\mathrm{~mA} \cdot \mathrm{cm}^{-2}\right)$ & 3 \\
$r$ & $\left(\mathrm{k} \Omega \cdot \mathrm{cm}^{2}\right)$ & $2.54 \times 10^{-4}$ \\
$i_{o}$ & $\left(\mathrm{~mA} \cdot \mathrm{cm}^{-2}\right)$ & 0.1 \\
$m$ & $(\mathrm{volts})$ & $2.11 \times 10^{-5}$ \\
$n$ & $\left(\mathrm{~cm}^{2} / \mathrm{mA}\right)$ & $8 \times 10^{-3}$ \\
\hline
\end{tabular}

where LHV is the lower heating value of hydrogen $(119860 \mathrm{~kJ} / \mathrm{kg})$ [19].

The amount of hydrogen and oxygen required to provide a certain current $I$ at the cell voltage $V_{\text {cell }}$ for one hour is obtained from the following relation [20]:

$$
\begin{aligned}
m_{\mathrm{H}_{2}} & =\frac{I}{z * F} * \frac{2.0158}{1000 * U_{\mathrm{H}_{2}}} * 3600 \mathrm{~kg}, \\
Q_{\mathrm{H}_{2}} & =\frac{m_{\mathrm{H}_{2}}}{0.08988} \mathrm{~m}^{3} \text { at STP, } \\
m_{\mathrm{O}_{2}} & =\frac{m_{\mathrm{H}_{2}}}{2.0158 * 2} * \frac{32}{1000 * U_{\mathrm{O}_{2}}} * 3600 \mathrm{~kg}, \\
Q_{\mathrm{O}_{2}} & =\frac{m_{\mathrm{O}_{2}}}{1.429} \mathrm{~m}^{3} \text { at STP, }
\end{aligned}
$$

where $U_{\mathrm{H}_{2}}$ and $U_{\mathrm{O}_{2}}$ are the utilization factors of hydrogen and oxygen, respectively. A lot of research is being conducted on the PEM fuel cells. The primary focus of ongoing research has been to improve performance and reduce cost. The principal areas of development are improved cell membranes, CO removal from the fuel stream, and improved electrode design. This of course leads to improvement in the utilization actor to values up to 0.96 [20]. Also, a recirculation mode may be utilized so that the unused gas is returned to the inlet by a compressor, or sometimes a passive device such as an ejector (based on a Venturi tube) may be employed. Thus, both utilization factors are assumed to have a value of 0.96 in this study.

Heat will be generated by the operation of the fuel cell since the enthalpy that is not converted to electrical energy will instead be converted to thermal energy. In order to operate the PEMFC at constant temperature, a cooling system must be added to absorb this heat and use it for cogeneration purposes [21]. That is, the heat output of the fuel cell will be utilized in the form of hot water which can also be used for heating purposes. A fuel cell stack will generate the following amount of heat during operation:

$$
\dot{Q}_{\text {total }}=\left(E_{\max }-V_{\text {cell }}\right) * I \text {, }
$$

where $E_{\max }$ is the maximum EMF of the fuel cell.

2.3. Economic Analysis. Renewable energy needs to be more competitive with conventional methods of power generation, that is, to have a lower cost on the long run. Thus, a very important part of the proposed model is to provide an economic study for the whole system. 
The main economic parameter that is studied is the cost of electricity (COE), which is the cost of producing one kWh of electricity. This parameter is believed to be the major criterion that indicates whether the system can be economically competitive to other conventional systems or not. Other factors that will be studied in this part are the total annual cost (TAC) including the capital cost equivalent and the operating cost.

2.3.1. Cost Items. The main cost items that are included in this estimate are

(1) photovoltaic panels,

(2) electrolyzer,

(3) hydrogen and oxygen storage tanks,

(4) battery,

(5) DC/AC converter (inverter),

(6) PEMFC stack including: cell, piping, and insulation,

(7) balance of plant (BOP),

(8) operating and maintenance cost $\left(\mathrm{C}_{O \& M}\right)$.

2.3.2. Capital Cost Estimation. The following assumptions are extracted from various literatures and are used to estimate the purchase cost of different system components excluding the taxes [22-24]:

(i) prevailing interest rate (ir $)=2 \%$,

(ii) average inflation rate $(f)=2.72 \%$ (On US $\$$ basis),

(iii) stack replacement cost $=1 / 3$ of stack initial cost (durability time $=40000 \mathrm{hr}$ )

(iv) Installation cost $=15 \%$ Purchase cost,

(v) operating and maintenance cost $=20 \%$ of annual fixed cost.

Also, the specifications as well as the cost of each of the system's components are shown in Table 4:

$$
\text { capital cost }\left(C_{\text {cap }}\right)=\text { purchase cost }+ \text { installation cost. }
$$

It is worth noting that the equivalent capital cost of each replacement cost of the PEMFC stack as well as the battery needs to be included in the capital cost of the system according to the following relation:

$$
\mathrm{C}_{\text {cap,replacement }}=\frac{\mathrm{C}_{\text {PEMFC,replacement }}}{\left(1+i r_{\mathrm{eff}}\right)^{n}}
$$

where $n$ is the number of years, calculated from the moment of installing the system, after which the stack will be replaced.

The effective annual interest rate ( $\left.i r_{\text {eff }}\right)$ is

$$
i r_{\text {eff }}=i r+f+i r * f
$$

TABle 4: Component's specification.

\begin{tabular}{lccc}
\hline Component & Price (US\$/Unit) & Replacement time (year) & Unit \\
\hline PV & 2780 & 20 & $1 \mathrm{~kW}$ \\
Electrolyzer & 800 & 20 & $1 \mathrm{~kW}$ \\
Storage tank & 750 & 20 & $1 \mathrm{~kg}$ \\
Inverter & 300 & 20 & $1 \mathrm{~kW}$ \\
PEMFC stack & 3000 & 5 & $1 \mathrm{~kW}$ \\
Battery & 250 & 5 & $1 \mathrm{~kW}$ \\
\hline
\end{tabular}

2.3.3. Estimation of (TAC) and (COE). The installation cost per kilowatt of system net electrical power can then be estimated as follows:

$$
\begin{gathered}
\text { Installation cost per } \mathrm{kW}_{\mathrm{e}} \\
=\frac{C_{\text {cap }}}{W_{\text {net,elec }}}(\$ / \mathrm{kW}),
\end{gathered}
$$

Annual fixed charge rate (AFCR)

$$
=\frac{i r_{\mathrm{eff}} *\left(1+i r_{\mathrm{eff}}\right)^{\text {life }}}{\left(1+i r_{\mathrm{eff}}\right)^{\text {life }}-1},
$$

Annual fixed charge

$$
=C_{\text {cap }} * \mathrm{AFCR} \text {, }
$$

Total annual cost (TAC)

$$
=\text { Annual fixed charge }+C_{\mathrm{O} \& M}(\$ / \mathrm{yr}) \text {, }
$$

Cost of electricity (COE)

$$
=\frac{\mathrm{TAC}(\$ / \text { year })}{W \text { net,elec }(\mathrm{kW}) * 24(\mathrm{hr} / \text { day }) * 365.25(\text { day } / \text { year })}(\$ / \mathrm{kWh}) .
$$

\section{Results and Discussion}

\subsection{Parametric Study}

3.1.1. Effect of Operating Temperature on Performance of the Electrolyzer. Two main key parameters affecting the performance of the electrolyzer are the current density and the operating temperature. Figure 3 shows that the voltage required by each cell of the electrolyzer increases as the current density supplied to the electrolyzer increases. This is due to the increase of the losses with the increase in the current density. On the other hand, the increase of the operating temperature of the electrolyzer causes a slight decrease in the voltage required by each cell of the electrolyzer at the same current density.

Detailed measurements of the hydrogen production at various current densities for the PHOEBUS electrolyzer (26 kW, 7 bar) were only available for an operation temperature of $80^{\circ} \mathrm{C}$. However, detailed experiments on the temperature sensitivity of the Faraday efficiency were performed on a very similar electrolyzer $(10 \mathrm{~kW}, 5 \mathrm{bar})$ installed at the HYSOLAR test and research facility for solar hydrogen 


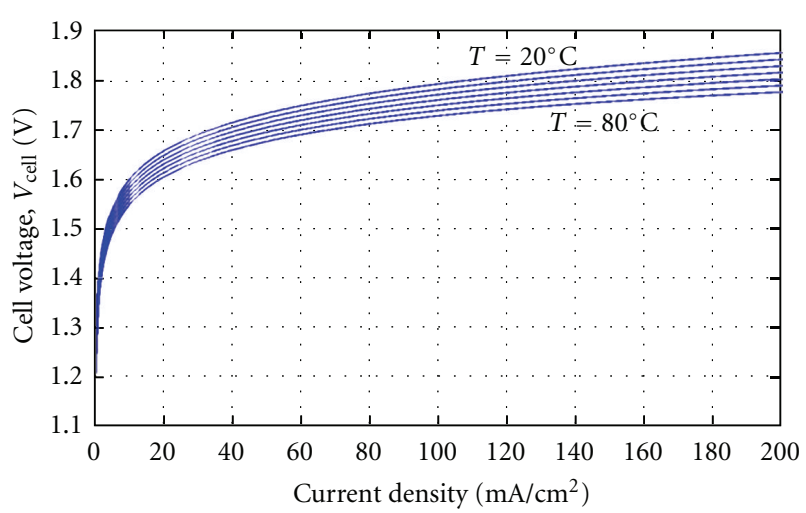

Figure 3: $I$ - $V$ curves for an electrolyzer cell at different temperatures.

TABLE 5: Faraday efficiency parameters for (11) for HYSOLAR test facility.

\begin{tabular}{lccc}
\hline$T\left({ }^{\circ} \mathrm{C}\right)$ & 40 & 60 & 80 \\
\hline$f_{1}\left(\mathrm{~mA}^{2} \mathrm{~cm}^{-4}\right)$ & 150 & 200 & 250 \\
$f_{2}$ & 0.990 & 0.985 & 0.98 \\
\hline
\end{tabular}

production in Stuttgart, Germany [2]. The values of the parameters obtained from these experiments at different temperatures are shown in Table 5.

Figure 4 shows the Faraday efficiency at $80^{\circ} \mathrm{C}$ of PHOEBUS electrolyzer.

Figure 5 demonstrates that the change in temperature has very slight effect on the Faraday efficiency. Also, it is clear that the Faraday efficiency is constant at current densities higher than $20 \mathrm{~mA} / \mathrm{cm}^{2}$.

3.1.2. Effect of Pressure and Temperature on Fuel Cell Performance. A parametric study was carried out by varying the cell pressure versus the Nernst voltage at different values of cell temperature $(333 \mathrm{~K}-363 \mathrm{~K})$. The obtained results are shown below in Figure 6. It is clear that Nernst voltage increases as the cell pressure increases. The Nernst voltage rises by an amount of approximately 0.05 volt from 1 bar to 9 bars. This increase means that the cell electrical efficiency increases with the increase in pressure. However, increasing the cell temperature causes a decrease in Nernst voltage by an amount of approximately 0.022 volt from 1 bar to 9 bars.

\subsubsection{Effect of Current Density on Fuel Cell Performance.} Figure 7 below shows the effect of current density on the three potential losses that occur in PEMFC as current is produced. It is clear that the increase in current density leads to an increase in all types of potential losses of the fuel cell. Combining the three potential losses and when subtracted from the Nernst voltage leads to the polarization curves of the PEMFC used in this work. Figure 8 shows the resulting polarization curves (actual operating voltage) at various operating pressures and at a temperature of $80^{\circ} \mathrm{C}$.

As shown in Figure 8, as current density increases, for a given cell pressure, the actual cell voltage decreases

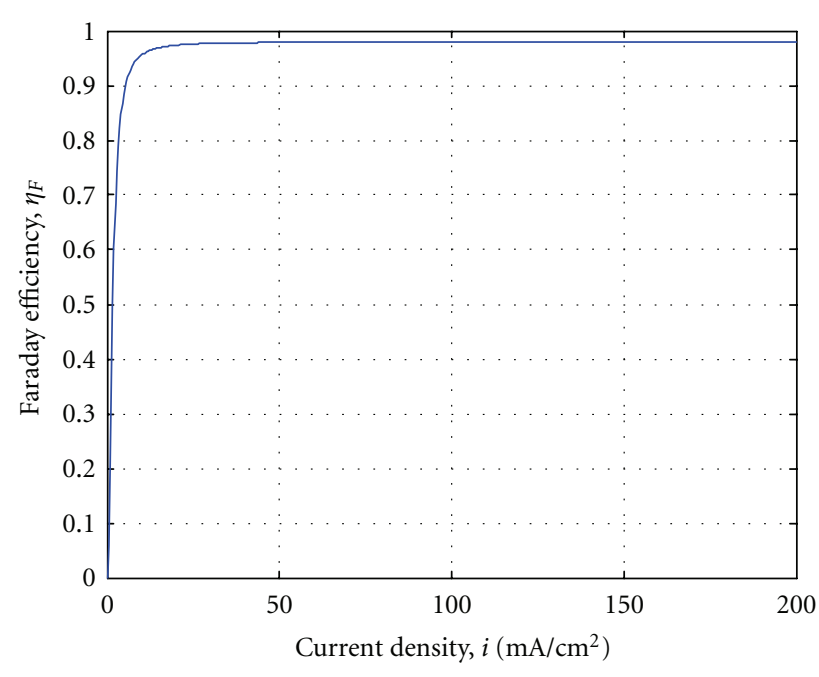

Figure 4: Faraday efficiency at $80^{\circ} \mathrm{C}$ of PHOEBUS electrolyzer.

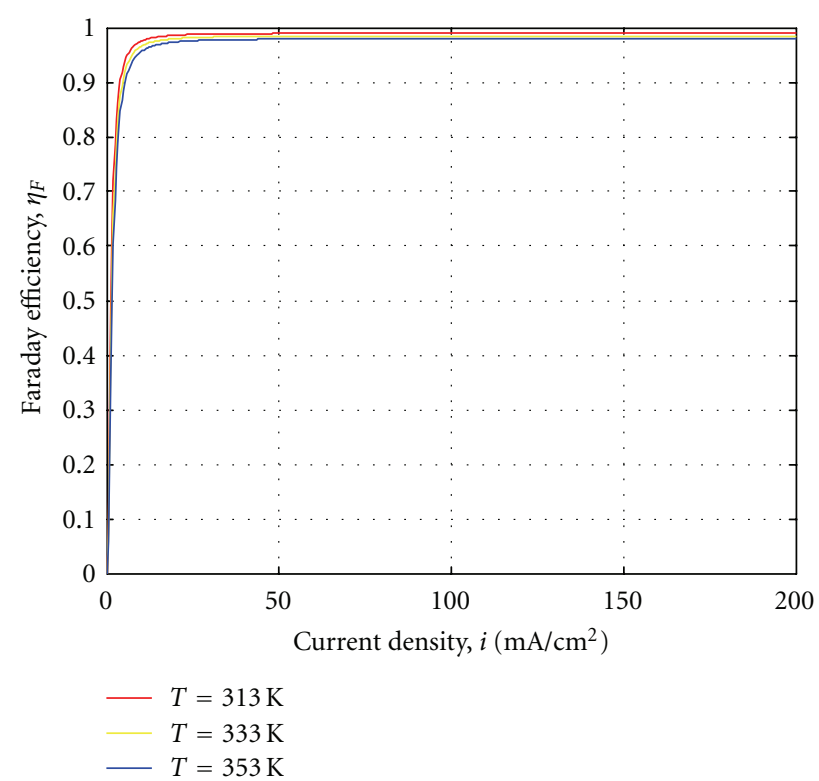

Figure 5: Faraday efficiency of HYSOLAR electrolyzer at different temperatures.

dramatically. As expected, at any given current density, the resulting voltage is higher for higher pressures, and hence the electrical efficiency would be also higher.

Figure 9 shows the effect of cell temperature change within the applicable range for PEMFCs $\left(70^{\circ} \mathrm{C}\right.$ to $\left.90^{\circ} \mathrm{C}\right)$ and current density, change on the cell voltage at a cell pressure of $1 \mathrm{bar}$. As explained earlier it is seen that the cell temperature very slightly affects the resulting voltage and hence will be considered of minor effect and the temperature for all forthcoming investigations will be fixed at $80^{\circ} \mathrm{C}$.

The above results are used to calculate the PEMFC electrical efficiency as a function of current density and cell operating pressure. Figure 10 shows the effect of current 


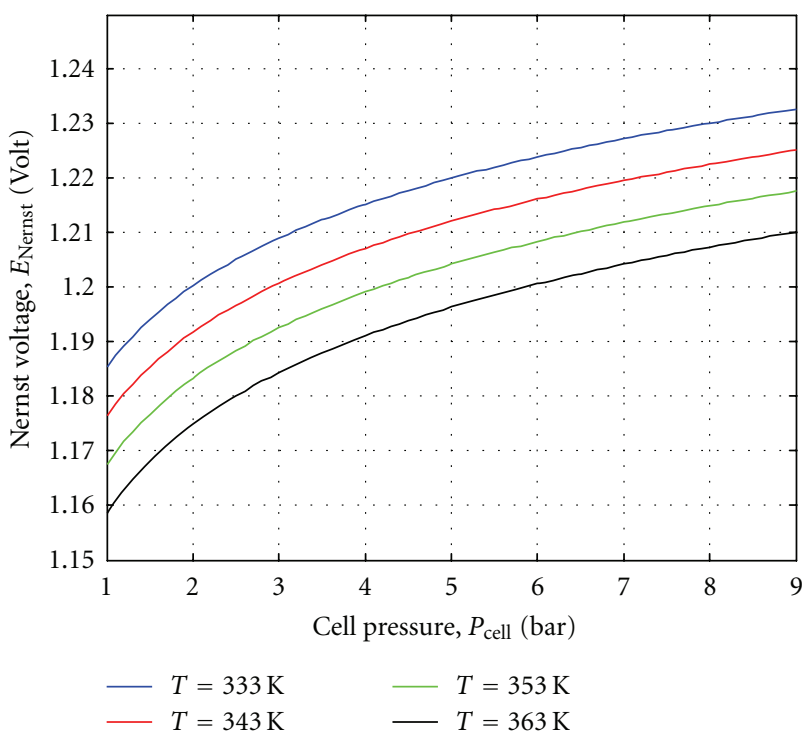

FIGURE 6: Effect of cell pressure on Nernst voltage at different cell temperatures

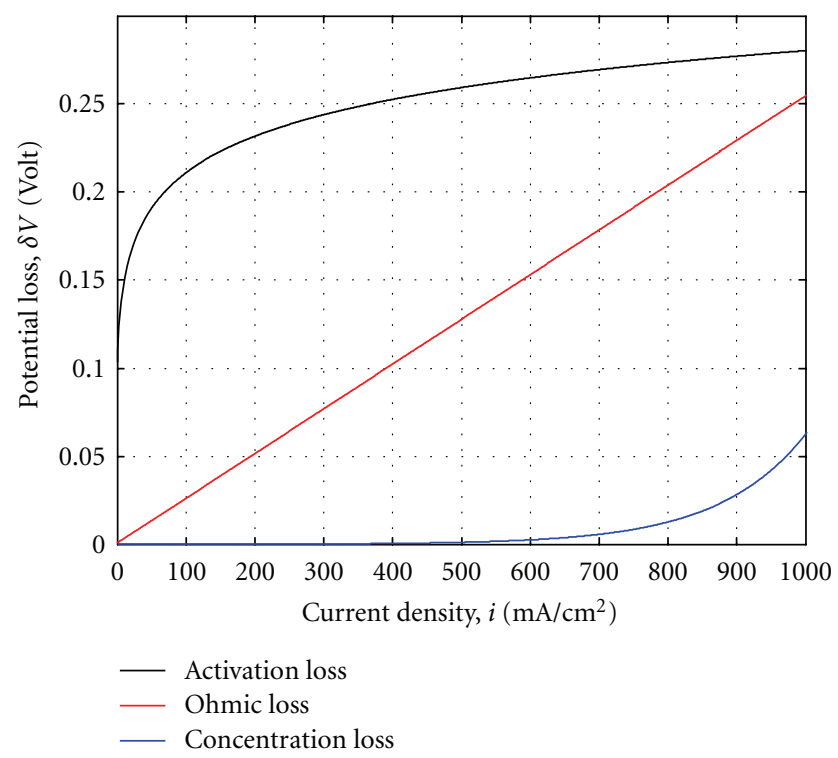

FIGURE 7: Effect of current density on different types of potential losses.

density on the cell electrical efficiency at different cell pressures and at a cell temperature of $80^{\circ} \mathrm{C}$.

It is seen from Figure 10 that, as current density increases, the cell efficiency decreases (due to actual voltage drop) starting from about $85 \%$ at no current (maximum ideal efficiency) and decreases down to $25 \%$ at $1200 \mathrm{~mA} / \mathrm{cm}^{2}$. As well, as explained earlier, it is seen that, at given current density, the electrical efficiency is higher for higher pressures.

As shown from the above results, the current density has a tremendous effect on the operating voltage and cell electrical efficiency (hence operating cost). Two important factors determine the range of acceptable operating current

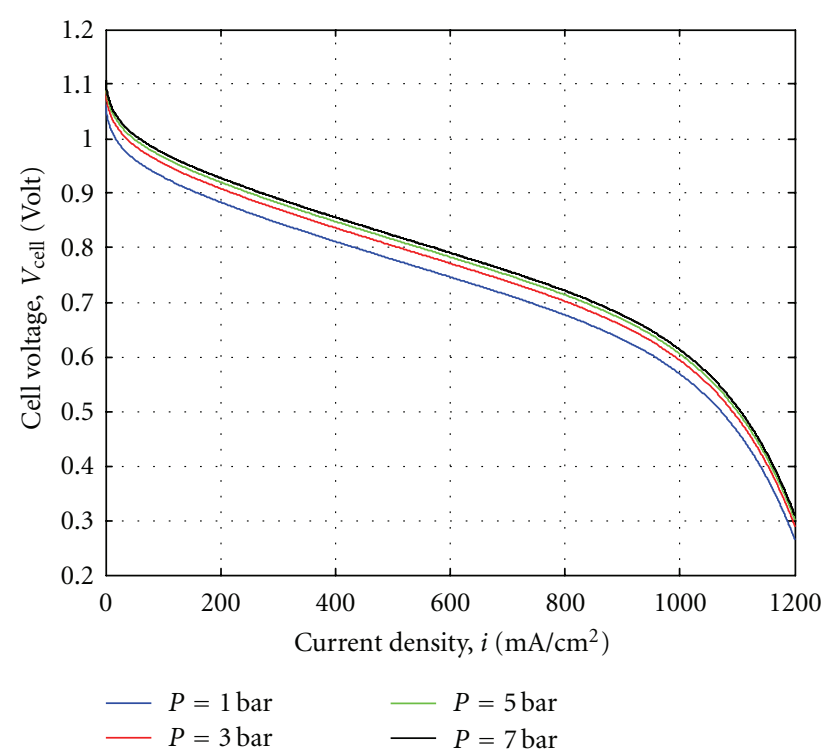

FIGURE 8: Effect of current density on cell voltage at different cell pressures $\left(T_{\text {cell }}=353 \mathrm{~K}\right)$.

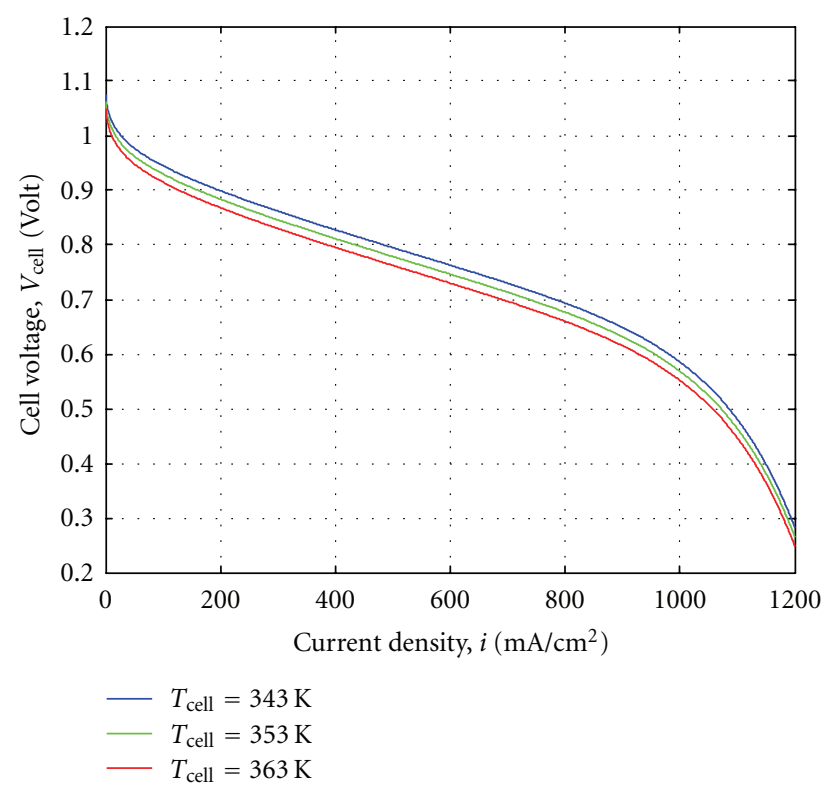

FIGURE 9: Effect of current density on cell voltage at different cell temperatures $\left(P_{\text {cell }}=1\right.$ bar $)$.

density: first, the obtained power density $\left(\mathrm{kW} / \mathrm{cm}^{2}\right)$ and, second, the lifetime cost of operation.

Figure 11 shows the effect of current density on the resulting power density. The power density is defined as the power output from the cell divided by the area required for the cell to produce this power.

Figure 11 shows also that as current density increases the power density increases until it reaches a peak then monotonically decreases. It would seem logical to design the cell to operate at the maximum power density that peaks 


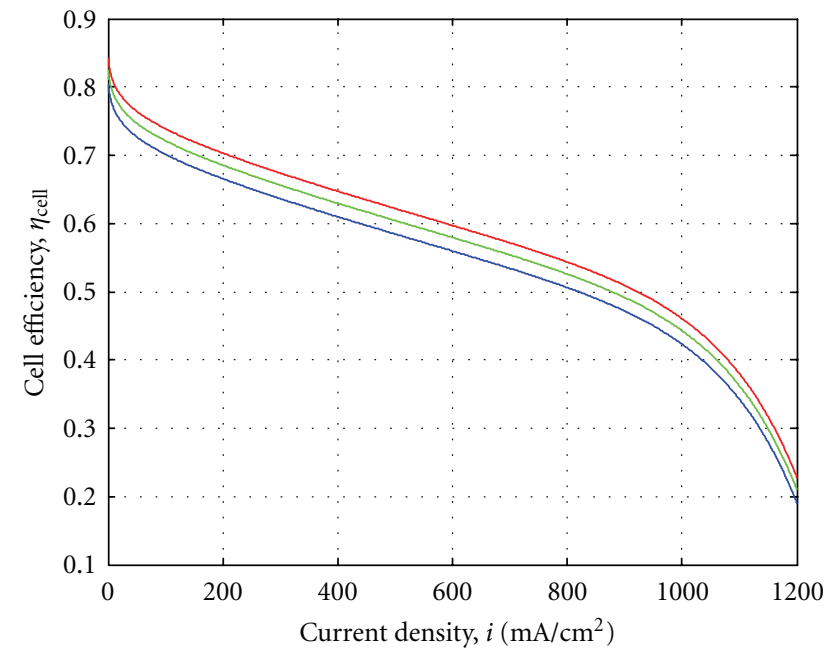

$$
\begin{aligned}
-P_{\text {cell }} & =1 \mathrm{bar} \\
-P_{\text {cell }} & =3 \mathrm{bar} \\
-P_{\text {cell }} & =8 \mathrm{bar}
\end{aligned}
$$

Figure 10: Effect of current density on cell electrical efficiency $\left(T_{\text {cell }}=353 \mathrm{~K}\right)$.

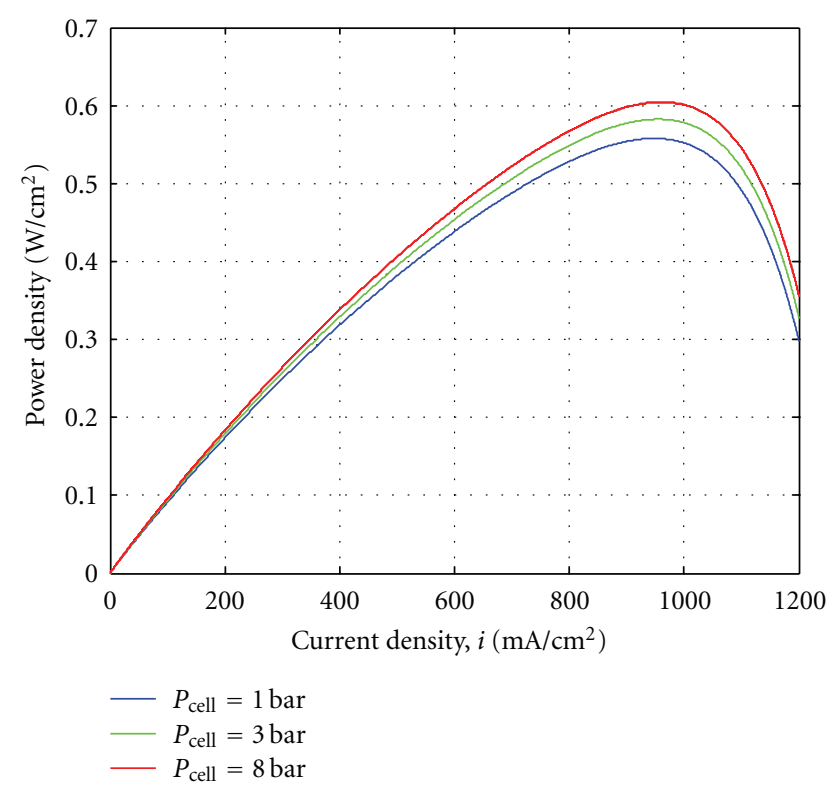

FIGURE 11: Effect of current density on power density $\left(T_{\text {cell }}=353 \mathrm{~K}\right)$.

at higher current density (off to the right of the figure at about $980 \mathrm{~mA} / \mathrm{cm}^{2}$ ). However, operation at the higher power densities will mean operation at lower cell voltages or lower cell efficiency. Setting operation at the peak power density can cause instability in control because the system would have a tendency to vacillate between higher and lower current densities around the peak. It is usual practice to operate the cell to the left side of the power density peak and at a point that yields lower life cycle cost of PEMFC operation, to which we now turn.
Abdel-Raouf [24] performed a life cycle analysis for a stand-alone PEMFC to determine the optimum range of operating current density. It was concluded that a range of current density of $400-800 \mathrm{~mA} / \mathrm{cm}^{2}$ yields lowest cost considering all the important parameters.

Based on this analysis, a value for the current density of $600 \mathrm{~mA} / \mathrm{cm}^{2}$ will be used in the analysis of PEMFC as a part of studying the performance of the proposed system in Cairo which is presented later on. This value is also consistent with the requirement of operation of the PEMFC to the left of the peak in the power density curve shown in Figure 11.

3.2. Optimization of the System Parameters. The aim of this part is to determine the optimum operating conditions of the system to obtain a yearly best total energy output taking Cairo data variations all over the year in consideration.

3.2.1. Operating Temperature of Electrolyzer. Decreasing the operating temperature of the electrolyzer causes an increase in the reversible voltage. This in turn decreases the volume of hydrogen produced as well as the amount of heat generated inside the electrolyzer as shown in Figure 12. On the other hand, this decrease in temperature leads to a decrease in the amount of heat loss from the electrolyzer to the surrounding which causes an increase in the proportion of heat absorbed by the cooling water.

In order to determine the optimum operating temperature of the electrolyzer, it is important to locate the point at which the lowest possible COE exists. Figure 13 shows that as the temperature of the electrolyzer decreases, the $\mathrm{COE}$ decreases.

It is worth noting that any excess amount of hydrogen that exceeds that required by the demand load throughout the year can be utilized either by the PEMFC to an extra load or by burning it to obtain extra heat. The COE of both cases is shown in Figure 13.

3.2.2. Operating Pressure of Electrolyzer and PEMFC. As mentioned before, the increase in the pressure of the electrolyzer causes a slight increase in the reversible voltage which in turn causes a decrease in the amount of hydrogen produced. Also, this increase in pressure and $V_{\text {rev }}$ at any temperature causes a decrease in the amount of heat generated inside the electrolyzer while the heat loss to the surrounding remains constant which causes a decrease in the amount of heat gained by the cooling water. This makes operating the electrolyzer at low pressure beneficial from the electrolyzer's point of view. However, the electrolyzer forces the hydrogen into the storage tanks from which the hydrogen flows into the PEMFC at night, and, as mentioned before, a high pressure of hydrogen is favourable for the PEMFC. Thus, a conflict exists between the optimum operating pressure of the electrolyzer and the PEMFC, and there are only 2 options available. The first one is to operate the electrolyzer at low pressure and then use a compressor to compress the hydrogen into the storage tanks at the optimum pressure of the PEMFC. It is clear that this option requires the purchase of a compressor which is expensive as well as increases the demand load to operate 


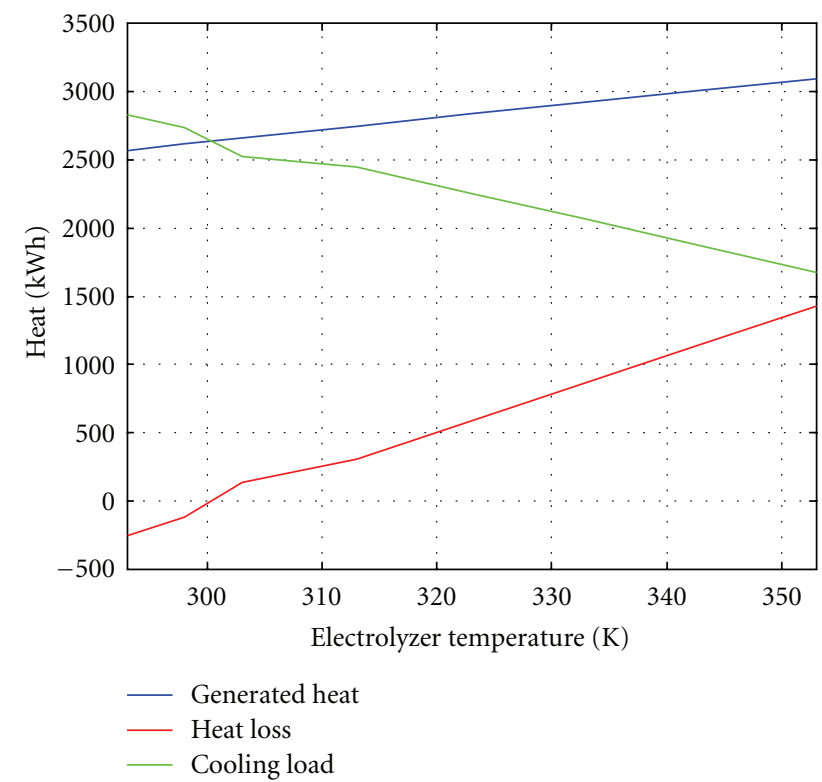

FIGURE 12: Effect of decreasing the operating temperature of the electrolyzer.

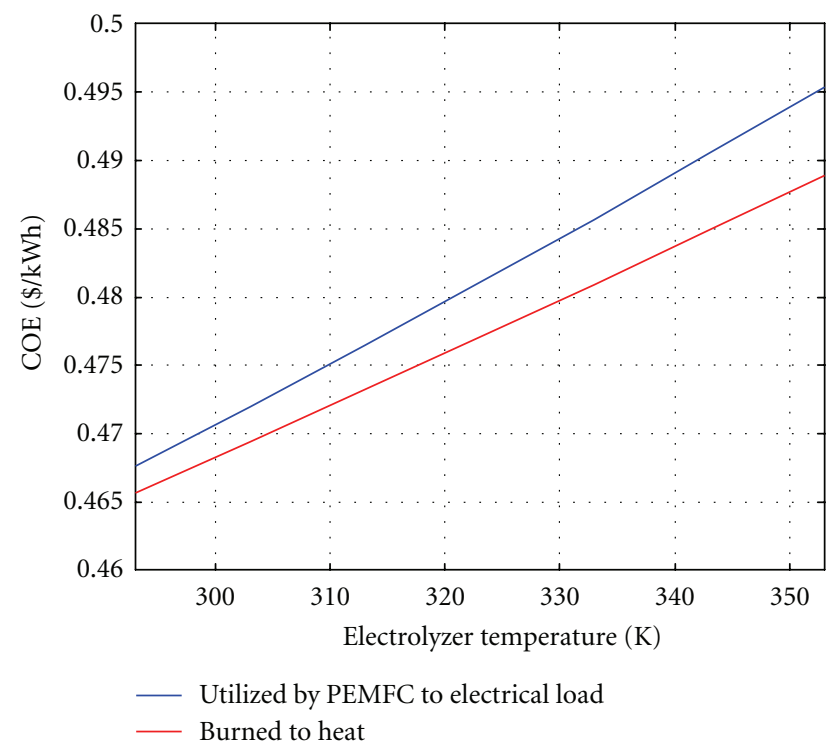

FIGURE 13: Effect of the operating temperature of the electrolyzer on the COE.

this compressor. On the other hand, a matching optimum pressure which lies in between the optimum pressures of the fuel cell and the electrolyzer can be determined. This pressure is simply located by determining the pressure at which the minimum COE is obtained.

Figure 14 below shows the change in the COE with operating pressure of both the electrolyzer and the PEMFC. It is clear that the optimum operating pressure is 4 bars.

3.2.3. Operating Temperature of PEMFC. As mentioned before, the cell temperature very slightly affects the resulting

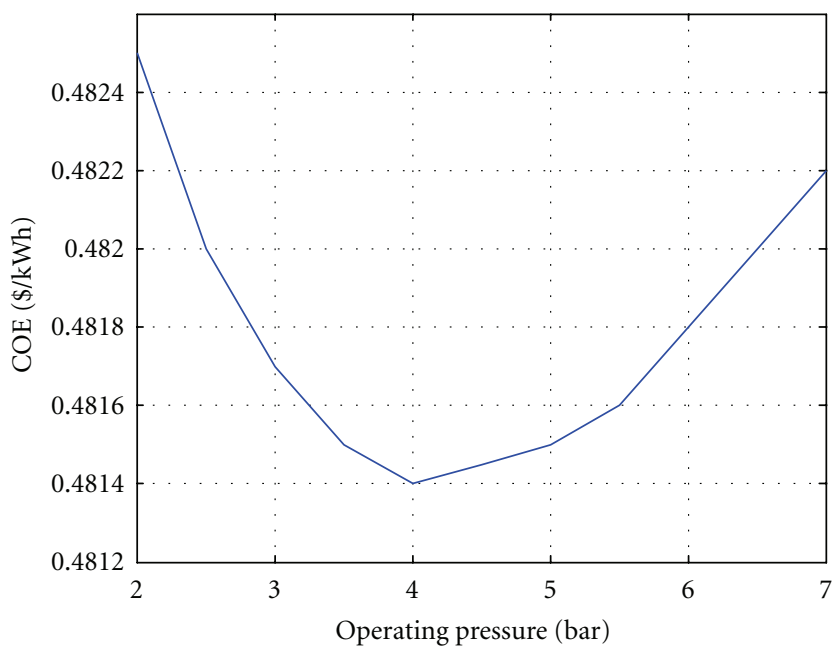

FIGURE 14: Effect of the operating pressure of the electrolyzer/ PEMFC on the COE.

voltage and hence will be considered of minor effect, and the operating temperature of the PEMFC will be fixed at $80^{\circ} \mathrm{C}$.

3.2.4. Current Density of PEMFC. As concluded before, a range of current density of $400-800 \mathrm{~mA} / \mathrm{cm}^{2}$ yields lowest cost considering all the important parameters. However, as the current density decreases, the cell voltage increases, as was shown in Figures 8 and 9, which means that less volume of hydrogen will be needed. Therefore, a value for the current density of $400 \mathrm{~mA} / \mathrm{cm}^{2}$ will be used which will cause a decrease in the number of PV modules installed to 45 instead of 52 at $800 \mathrm{~mA} / \mathrm{cm}^{2}$. The effect of decreasing the current density on the COE is shown in Figure 15.

For the PEMFC, at $T_{\text {cell }}=80^{\circ} \mathrm{C}, P_{\text {cell }}=4 \mathrm{bar}, i=$ $400 \mathrm{~mA} / \mathrm{cm}^{2}$, and in order to generate $1 \mathrm{kWh}$ of electricity, it is found that
(i) $V_{\text {cell }}=0.8433 \mathrm{~V}$,
(ii) $I=1.1859 * 10^{3} \mathrm{~A}$,
(iii) $m_{\mathrm{H} 2}=0.0465 \mathrm{~kg}$,
(iv) $Q_{\mathrm{H} 2}=0.5168 \mathrm{~m}^{3}$ at STP,
(v) $m_{\mathrm{O} 2}=1.3827 \mathrm{~kg}$,
(vi) $Q_{\mathrm{O} 2}=0.9676 \mathrm{~m}^{3}$ at STP,
(vii) $\eta_{\text {cell }}=64.66 \%$,
(viii) $\eta_{\text {cell,cogeneration }}=84.34 \%$.

3.2.5. Effect of Reduction of Cost of PEMFC. It is clear in Figure 16 below that the COE of the proposed system is directly and linearly dependent on the cost of the PEMFC. A decrease of the cost of the PEMFC by $92.5 \%$ (from $3000 \$$ to $225 \$$ ) causes a decrease in the COE of the system by around $37 \%$.

Combining the expected future increase of PV efficiency up to $30 \%$ with the decrease of the cost of PEMFC will yield a COE of $0.212 \$ / \mathrm{kWh}$ for the proposed system. This value will be small when compared to COE of 


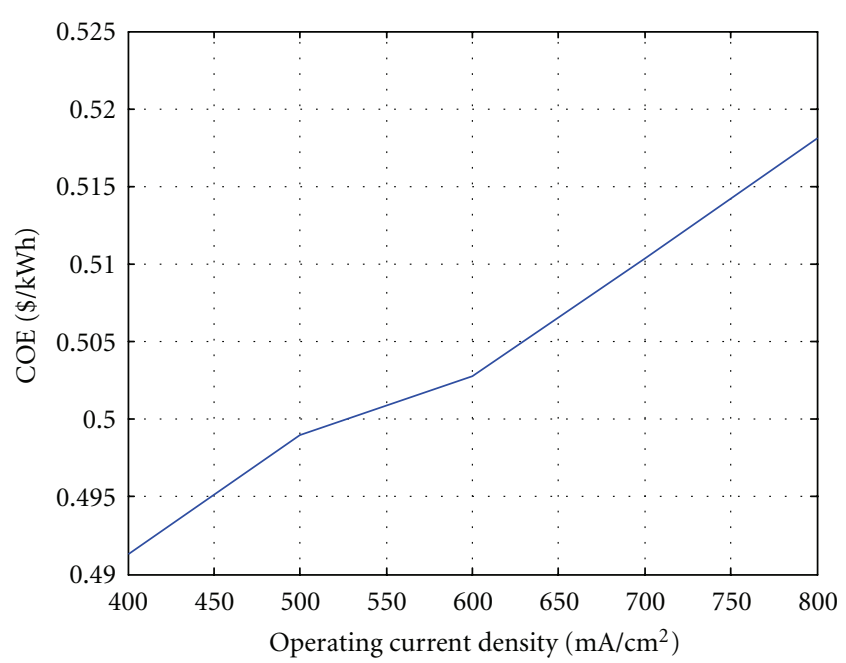

FIGURE 15: Effect of the operating current density of PEMFC on the COE.

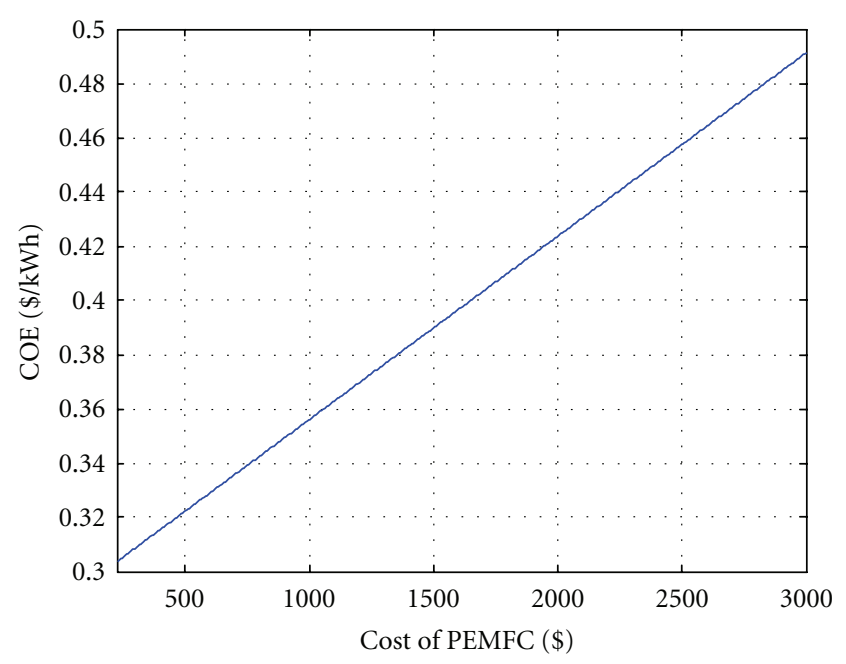

Figure 16: Effect of cost of PEMFC on COE.

(i) $0.2798 \$ / \mathrm{kWh}$ of a system comprising PV arrays and batteries in the future

(ii) $0.3088 \$ / \mathrm{kWh}$ by using a diesel generator recently (with expected increase of price of diesel in the future).

On the other hand, this COE is still 3 times higher than the current COE for a grid-connected house $(0.0717 \$ / \mathrm{kWh})$. However, the on-grid COE is expected to increase in the future.

\section{Conclusions and Recommendations}

The aim of this work is to study and model a proposed stand-alone power system utilizing solar energy as its power source and comprising photovoltaic arrays, an alkaline electrolyzer, storage tanks, secondary battery banks, and a proton exchange membrane fuel cell as its main components.
The effect of each of the key parameters affecting the amount of solar radiation and the performance of the PV arrays, alkaline electrolyzer, and the PEMFC were studied. Also, an economic study was performed to determine the feasibility of the proposed system to be used on a residential scale. The modeling outcomes of this system were performed for Cairo city in Egypt using the developed program with the aid of MATLAB code.

The proposed model can predict the performance of a stand-alone power system. It can predict the output power of the system as a whole in any location as well as the effect of different parameters on its performance. Also, it can predict the output of each of the system components such as the output power of the PV arrays, the volume of hydrogen produced by the electrolyzer, and the electric as well as heat output of the PEMFC.

The variations of the output of this system were determined for Cairo city in Egypt at different periods throughout the year. It was clear that the PV power varies in the same manner as the radiation on the PV surface which reaches its peak at the solar noon. Also, the efficiency of the PV, tilted at $30^{\circ}$, is almost constant throughout the year with slight variations between the different months. Moreover, the proposed system produces an excess amount of hydrogen more than the amount required to satisfy the demand load during some months of the year. This excess hydrogen is used to satisfy the deficit in the other months so that the system can easily satisfy the estimated maximum demand load of the studied residential unit.

Furthermore, the proposed system has a COE of 49 cents/kWh, at an efficiency of $9.87 \%$, which is high relative to the COE of using a PV and a battery only, using diesel generator, or a similar grid-connected house. However, as the market for fuel cells penetrate more and as the new higher efficiency PV systems become commercially available, this cost is expected to decrease to 21 cents $/ \mathrm{kWh}$ in the near future which will make the proposed system a very competitive option, especially with its zero pollutants emissions to the environment.

\section{References}

[1] H. A. Khater, A. A. Abdelraouf, and M. H. Beshr, "Modeling of an Optimized Photovoltaic (PV) Array with Hydrogen System Comprising a Proton Exchange Membrane Fuel Cell (PEMFC) and an Electrolyser," in Proceedings of AIAA 8th Annual International Energy Conversion Engineering Conference, 2010.

[2] Ø. Ulleberg, "Modeling of advanced alkaline electrolyzers: a system simulation approach," International Journal of Hydrogen Energy, vol. 28, no. 1, pp. 21-33, 2003.

[3] R. L. LeRoy, "Industrial water electrolysis: present and future," International Journal of Hydrogen Energy, vol. 8, no. 6, pp. 401417, 1983.

[4] P. M. Diéguez, A. Ursúa, P. Sanchis, C. Sopena, E. Guelbenzu, and L. M. Gandía, "Thermal performance of a commercial alkaline water electrolyzer: experimental study and mathematical modeling," International Journal of Hydrogen Energy, vol. 33, no. 24, pp. 7338-7354, 2008.

[5] R. J. Gilliam, J. W. Graydon, D. W. Kirk, and S. J. Thorpe, "A review of specific conductivities of potassium hydroxide 
solutions for various concentrations and temperatures," International Journal of Hydrogen Energy, vol. 32, no. 3, pp. 359364, 2007.

[6] G. D. Berry, "Hydrogen production," in Encyclopedia of Energy, vol. 3, Elsevier-Academic Press, San Diego, Calif, USA, 2004.

[7] M. Nadal and F. Barbir, "Development of a hybrid fuel cell/battery powered electric vehicle," International Journal of Hydrogen Energy, vol. 21, no. 6, pp. 497-505, 1996.

[8] A. Ramadan, E. El Shenawy, A. Abdel Dayem, and S. Eid, "Optimization of PV-hydrogen electrolyzes system," in the 3rd International Conference on Engineering Science \& Technology, Cairo, Egypt, 2008.

[9] G. Schiller, R. Henne, P. Mohr, and V. Peinecke, "High performance electrodes for an advanced intermittently operated $10-\mathrm{kw}$ alkaline water electrolyzer," International Journal of Hydrogen Energy, vol. 23, no. 9, pp. 761-765, 1998.

[10] M. P. M. Kaninski, A. D. Maksić, D. Lj. Stojić, and S. S. Miljanic, "Ionic activators in the electrolytic production of hydrogen - cost reduction-analysis of the cathode," Journal of Power Sources, vol. 131, no. 1-2, pp. 107-111, 2004.

[11] P. Vermeiren, W. Adriansens, J. P. Moreels, and R. Leysen, "Evaluation of the zirfon $(\mathrm{B}$ ) separator for use in alkaline water electrolysis and Ni-H2 batteries," International Journal of Hydrogen Energy, vol. 23, no. 5, pp. 321-324, 1998.

[12] K. Onda, T. Kyakuno, K. Hattori, and K. Ito, "Prediction of production power for high-pressure hydrogen by highpressure water electrolysis," Journal of Power Sources, vol. 132, no. 1-2, pp. 64-70, 2004.

[13] M. P. Rzayeva, O. M. Salamov, and M. K. Kerimov, "Modeling to get hydrogen and oxygen by solar water electrolysis," International Journal of Hydrogen Energy, vol. 26, no. 3, pp. 195-201, 2001.

[14] A. Roy, S. Watson, and D. Infield, "Comparison of electrical energy efficiency of atmospheric and high-pressure electrolysers," International Journal of Hydrogen Energy, vol. 31, no. 14, pp. 1964-1979, 2006.

[15] D. Thirumalai and R. E. White, "Mathematical modeling of proton-exchange-membrane fuel-cell stacks," Journal of the Electrochemical Society, vol. 144, no. 5, pp. 1717-1723, 1997.

[16] R. F. Mann, J. C. Amphlett, M. A. I. Hooper, H. M. Jensen, B. A. Peppley, and P. R. Roberge, "Development and application of a generalized steady-state electrochemical model for a PEM fuel cell," Journal of Power Sources, vol. 86, no. 1, pp. 173-180, 2000.

[17] J. Wishart, M. Secanell, and Z. Dong, "Optimization of a fuel cell system based on empirical data of a PEM fuel cell stack and the generalized electrochemical model," in Proceedings of the International Green Energy Conference, Waterloo, Canada, 2005, Paper No. 126.

[18] V. Gurau, S. Kakac, and H. Liu, "Mathematical model for proton exchange membrane fuel cells," in Proceedings of the ASME International Mechanical Engineering Congress and Exposition, pp. 205-214, November 1998.

[19] J. Kim, S. M. Lee, S. Srinivasan, and C. E. Chamberlin, "Modeling of proton exchange membrane fuel cell performance with an empirical equation," Journal of the Electrochemical Society, vol. 142, no. 8, pp. 2670-2674, 1995.

[20] US Department of Energy, Fuel Cell Handbook, National Energy Technology Laboratory, 7th edition, 2004.

[21] O. Yamamoto, "Solid oxide fuel cells: fundamental aspects and prospects," Electrochimica Acta, vol. 45, no. 15-16, pp. 2423 $2435,2000$.

[22] http://www.bankrate.com/.
[23] http://www.tradingeconomics.com/united-states/inflation-cpi.

[24] Y. A. M. A. Abdel-Raouf, Parametric investigation and economic analysis of stand-alone and hybrid Proton Exchange Membrane (PEM) fuel cell system, M.S. thesis, Cairo University, Cairo, Egypt, 2009. 

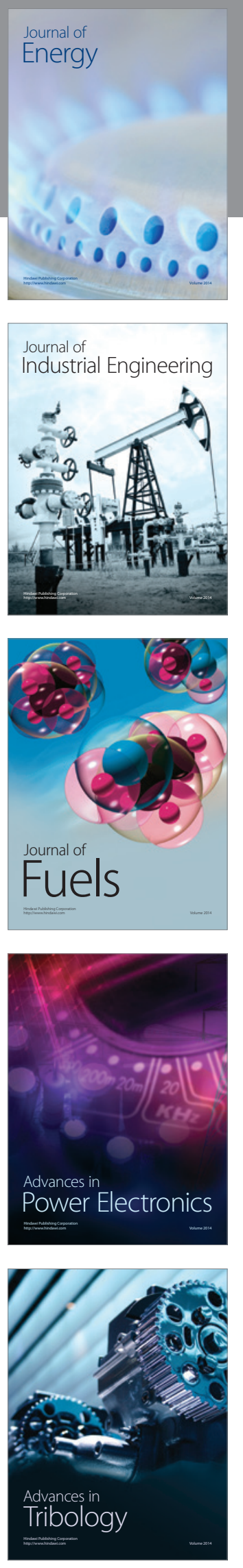
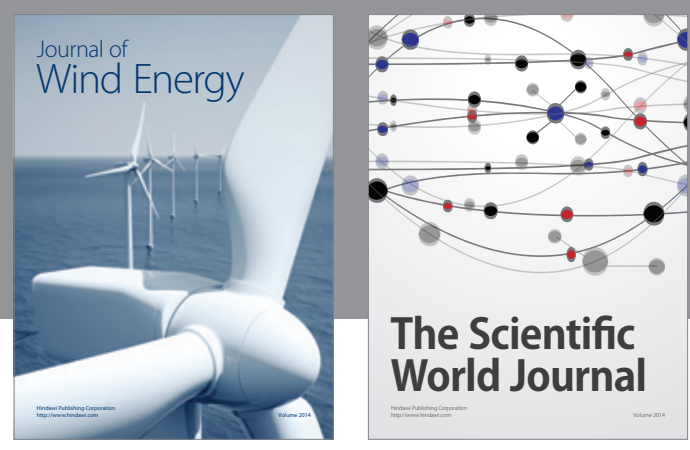

The Scientific World Journal

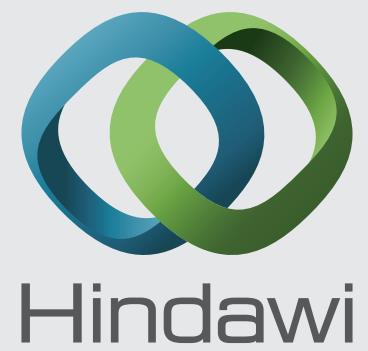

Submit your manuscripts at http://www.hindawi.com
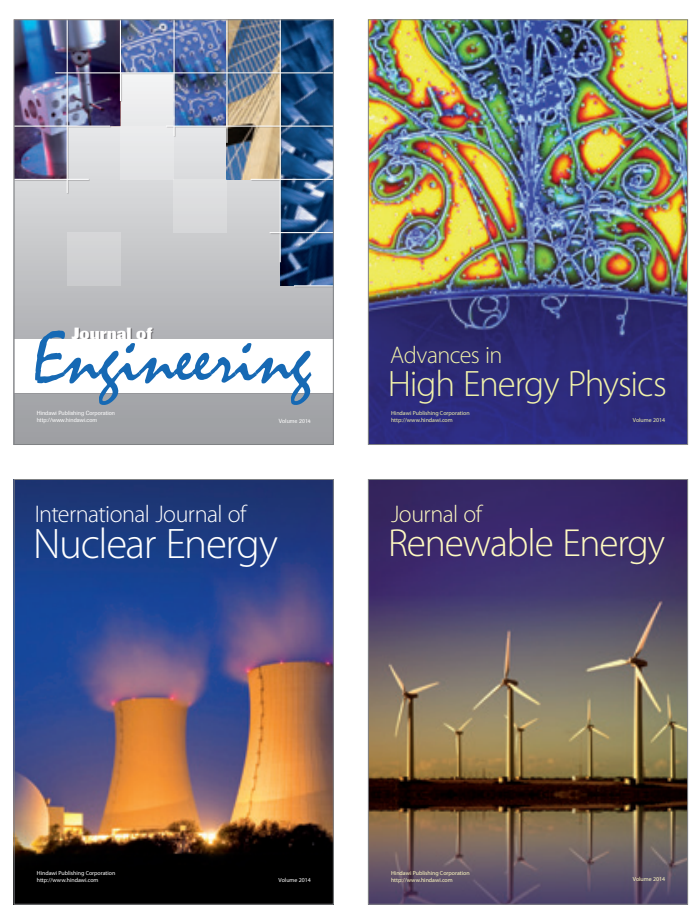

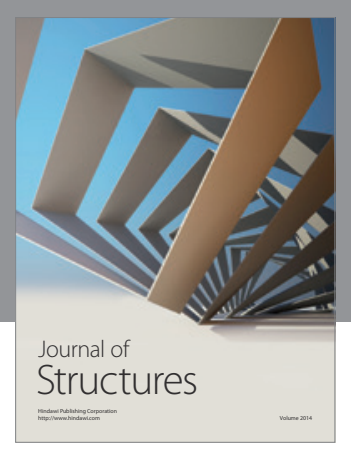

Rotating
Mechinery
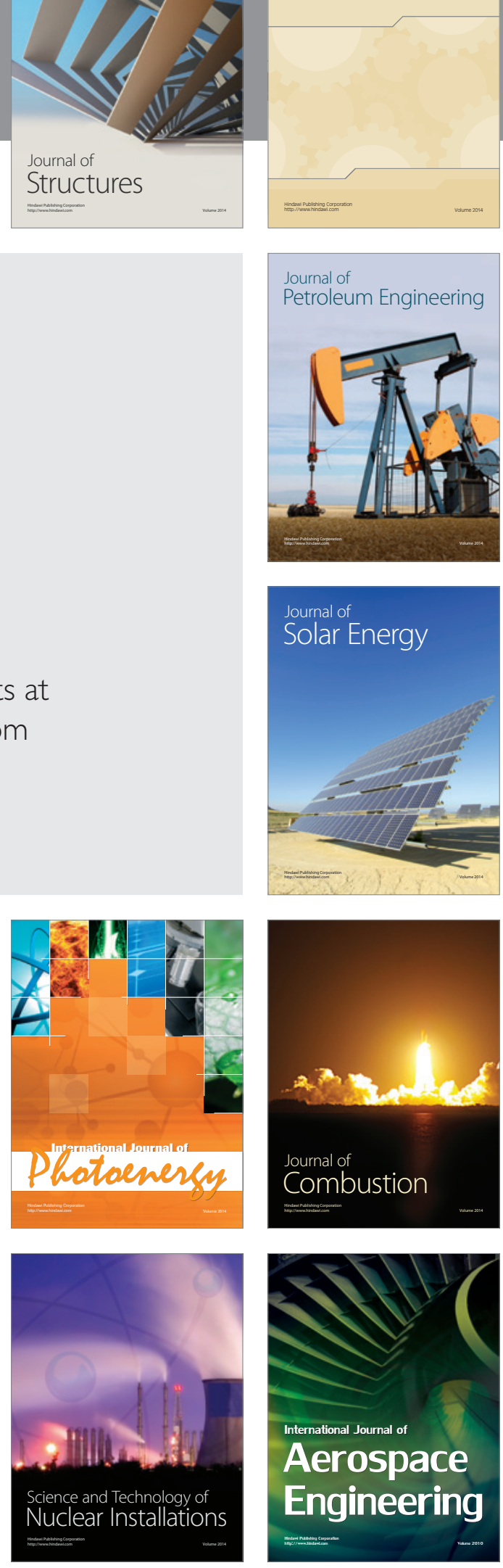